\title{
Safe Areas for the Placement of Standard Shoulder Arthroscopy Portals. An Anatomical Study
}

\author{
Áreas Seguras para la Colocación de Portales Artroscópicos \\ Estándar de Hombro. Un Estudio Anatómico
}

\begin{abstract}
Abraham G. Espinosa-Uribe*; Rodolfo Morales-Avalos*; Jorge Gutiérrez-de la O*; Oscar R. García-de León*; Jessica K. Torres-García"; Katia Guzmán-Avilán*; Félix Vílchez-Cavazos**; Oscar de la Garza-Castro*; Santos Guzmán-López** \& Rodrigo E. Elizondo-Omaña*
\end{abstract}

ESPINOSA-URIBE, A. G.; MORALES-AVALOS, R.; GUTIÉRREZ-DE LA O, J.; GARCÍA-DE LEÓN, O. R.; TORRESGARCÍA, J. K.; GUZMÁN-AVILÁN, K.; VÍLCHEZ-CAVAZOS, F.; DE LA GARZA-CASTRO, O.; GUZMÁN-LÓPEZ, S. \& ELIZONDO-OMAÑA, R. E. Safe areas for the placement of standard shoulder arthroscopy portals. An anatomical study. Int. J. Morphol., 33(4):1386-1392, 2015.

SUMMARY: The abundant vascular structures that surround the shoulder joint are complex and variable, complicating arthroscopy approaches. The aim of this study is to determine safe and risky areas around standard posterior and standard anterior portals, and accounting for the distribution of neurovascular structures of small and medium diameters that can lead to intra-articular bleeding during surgery. The standard posterior portal, and standard anterior portal were placed as described in the literature, and punch dissection was performed $2.5 \mathrm{~cm}$ around the trocar in situ. The arrangement of each identified structure was photographically documented and digitalized for each anatomic plane; the distance to the trocar and the diameter of each structure were measured. Based on each digitalized anatomic plane, safe and risky tissue areas were determined, and a clock face coordinate system was used to represent these areas. The safe area around the standard posterior portal was located between 11 and 1 o'clock for the left shoulder and 11 and 2 o'clock for the right shoulder. For the standard anterior portal, the safe area was located between 2 and 3 o'clock for the left shoulder and between 9 and 12 o'clock for the right shoulder. However, we did document a risk of injuring the cephalic vein 5 times, the axillary artery 3 times and the deltoid branch of the thoracoacromial artery once. This study reports quantitatively the total number of small diameter structures present in the two shoulder arthroscopic portals evaluated. The safe areas proposed in this study must be evaluated to propose new access points for performing arthroscopic procedures on the shoulder.

KEY WORDS: Anatomy; Arthroscopy; Portals; Safe Areas; Shoulder.

\section{INTRODUCTION}

Shoulder arthroscopy is a technique that allows the detailed exploration of the anatomical structures of the glenohumeral joint. Although the prevalence of complications is relatively low, one cause of complications during arthroscopic procedures of the shoulder is injury to neurovascular structures due to tissue manipulation while positioning the portal (Pope et al., 2011; Meyer et al., 2007). These injuries can lead to intra-articular bleeding, which often complicates visualization while performing an arthroscopic approach.

The abundant neurovascular structures surrounding the shoulder joint are complex and frequently present anatomical variants that complicate the placement of arthroscopy portals (Stecco et al., 2010). For example, during the placement of posterior portals, risks of injuring the posterior humeral circumflex artery (Naidoo et al., 2014), the circumflex artery of the scapula (Ebraheim et al., 2010), the suprascapular nerve (Bigliani et al., 1990; Shishido \& Kikuchi, 2001; Gumina et al., 2011), branches of the infraspinous artery (Naidoo et al.), and muscle vessels that provide irrigation to the joint capsule have been documented (Andary \& Petersen, 2002). During the placement of anterior portals, their proximity to the cephalic vein (Di Giacomo \& Costantini, 2004; Meyer et al.), anterior humeral circumflex artery, and musculocutaneous nerve has been described (Di Giacomo \& Costantini).

\footnotetext{
" Department of Human Anatomy, Faculty of Medicine, Universidad Autónoma de Nuevo León, Nuevo León, México.

** Orthopedics and Traumatology Service, University Hospital “Dr. José Eleuterio González”, Universidad Autónoma de Nuevo León, Nuevo León, México.
} 
ESPINOSA-URIBE, A. G.; MORALES-AVALOS, R.; GUTIÉRREZ-DE LA O, J.; GARCÍA-DE LEÓN, O. R.; TORRES-GARCÍA, J. K.; GUZMÁN-AVILÁN, K.; VÍLCHEZ-CAVAZOS, F.; DE LA GARZA-CASTRO, O.; GUZMÁN-LÓPEZ, S. \& ELIZONDO-OMAÑA, R. E. Safe areas for the placement of standard shoulder arthroscopy portals. An anatomical study. Int. J. Morphol., 33(4):1386-1392, 2015.

The creation of portals that allow adequate joint visualization, a safe approach angle, and a suitable range of surgical movement is an important consideration in arthroscopy (Di Giacomo \& Costantini). A safe area is considered as that with a low presence of neurovascular structures, and an area of risk is that with a higher number of anatomical structures.

Anatomical variations in this region complicate the establishment of new arthroscopic portals that are better than those currently used (Andrews et al., 1984). We found little information in the current literature on the location of safe areas around the points where the most frequently used access portals are placed during shoulder arthroscopy.

Although previous studies have determined the ratio close to the conventional portals for shoulder arthroscopy neurovascular structures, the safe and risky areas near these portals remain unknown. The aim of this study is to determine the safe areas around the standard posterior (SPP) and anterior (SAP) portals used in shoulder arthroscopy. This study's hypothesis states that there are safe and risky areas in relation to the two most used standard arthroscopic portals in the shoulder, and these areas can be used to minimize the possibility to neurovascular injury and prevent intraarticular bleeding.

\section{MATERIAL AND METHOD}

An anatomic, descriptive, observational, crosssectional study was performed. Thirteen shoulders from embalmed cadavers with an age range between 18 and 60 years (mean 40.4 \pm 9.12 ), weight between 52.40 and 96.00 $\mathrm{kg}$ (mean 69.54 \pm 13.6 ), height between 1.52 and 1.89 meters (mean 1.67 \pm 0.22 ) and body mass index between 19.21 and $32.37 \mathrm{~kg} / \mathrm{m}^{2}$ (mean 24.88 \pm 3.88 ), were included. Seven male cadavers were evaluated. A left shoulder with an anterior dislocation was excluded.

The standard surgical protocol for the body position, upper limb traction, as well as portal location and positioning was followed. The body was placed in the lateral decubitus position, the upper extremity was placed in $15^{\circ}$ abduction, and traction was applied downward with a weight of $9.71 \mathrm{~kg}$ (20 lbs) (Fig. 1). Subsequently, bony landmarks of the acromion, clavicle and acromioclavicular joint were identified and marked using a surgical marker. Finally, the SPP, and SAP were placed following the classic description in the literature (McGinty et al., 2005; Meyer et al.; Gumina et al.). Although there are other shoulder portals (not evaluated in this study), SPP and SAP are the most commonly used.
The SPP was placed according to the descriptions of Andrews et al. and Wolf (1989) at a point located $2 \mathrm{~cm}$ inferior and $2 \mathrm{~cm}$ medial to the posterolateral border of the acromion, directing the trocar towards the coracoid process (Andrews et al.; Wolf). The SAP was placed in the rotator space or the rotator triangle formed by the subscapularis tendon, the humeral head, and the tendon of the long head of the biceps. To conduct this study, this portal was placed using the "inside-out" technique, which involves directing the arthroscope through this triangle, just lateral to the coracoid process (Di Giacomo \& Costantini; Meyer et al.; Burkhart et al., 2012).

After placing the SPP and arthroscopically identifying the rotator triangle references, the SAP was placed. Following portal placement, the dissections were performed using the "punch technique" (this is an original dissection technique devised by the authors). This technique involves dissecting each anatomical plane (dissecting between adipose tissue, muscle fascia and muscle fibers) within a radius of $2.5 \mathrm{~cm}$, with the trocar (Linvatec T4930, $4 \mathrm{~mm}$ in diameter) considered as the center (Fig. 2). This technique allows for the better establishment of the in situ relationship between the trocar and the neurovascular structures at risk of being injured. Topographically, all anatomical planes were dissected down to the joint capsule.

For each neurovascular structure found, the following morphometric characteristics were determined by two persons: diameter, distance to the trocar, anatomical plane and position within the dissection circumference of each structure in situ.

The position of each neurovascular structure identified was documented by standardized photography for each portal (using a Nikon $®$ D 3200, 24 mpx digital camera). Each measurement was independently performed by two persons who were blinded to each other. For the measurements (in millimeters), a digital vernier caliper with an accuracy of $0.01 \mathrm{~mm}$ was used (Mitutoyo ${ }^{\circledR}$ Digimatic w/Absolute Encoders Series 500). Based on the photographs, each structure for each anatomic plane was digitalized using Adobe Illustrator@ CS6 for Mac OS@10.6 (Fig. 3). Once digitalized, each anatomic plane was overlapped to identify risky areas with more neurovascular structures near the in situ trocar and safe areas where there are fewer structures at risk for each portal (the computational method of analysis used in our study represents a new technique devised by the authors and is based on the concept of creating volumes of security and risk results overlaying the areas of security and individual risk for each anatomical plane). 

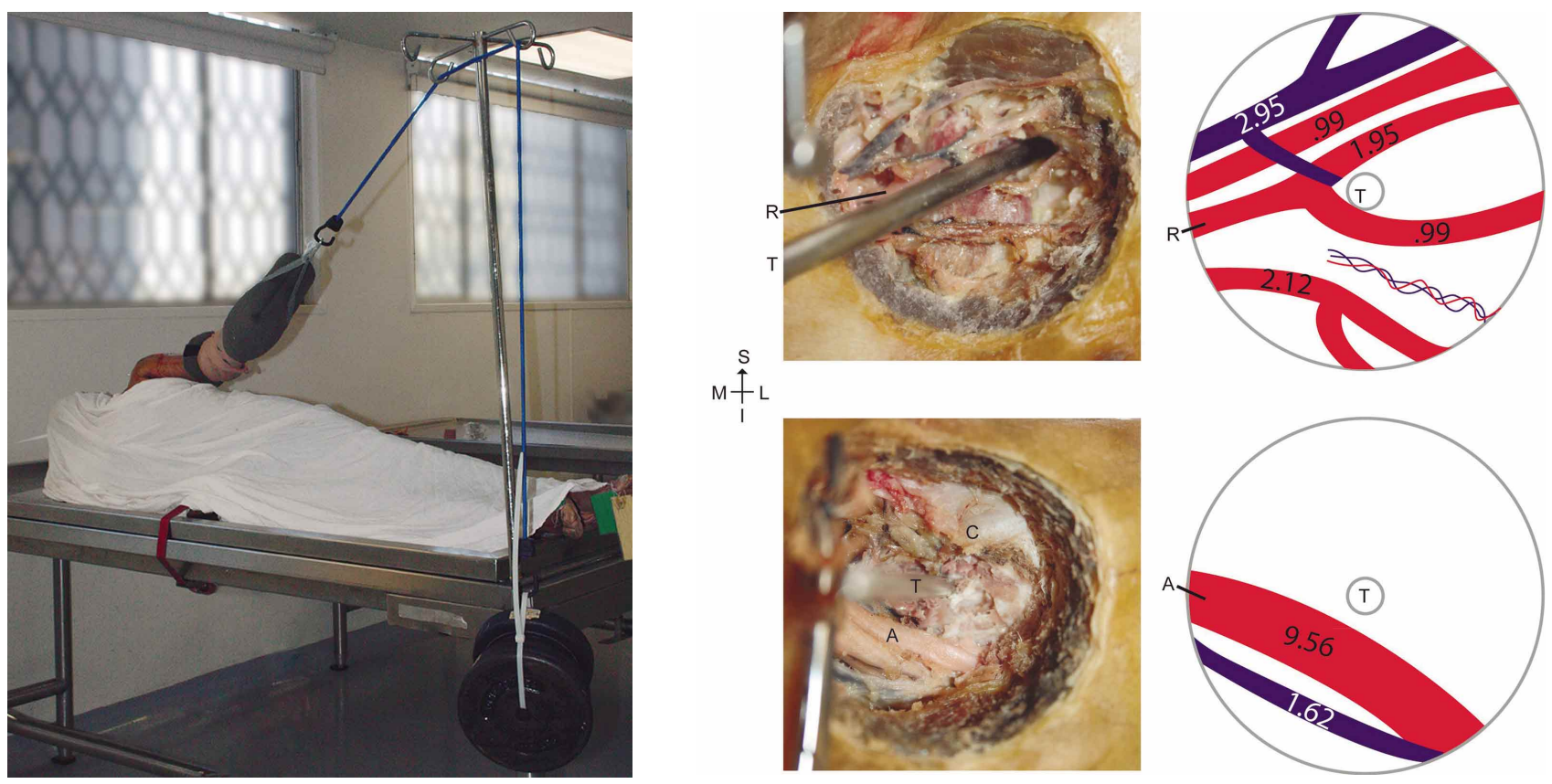

Fig. 1. Positioning the body for the placement of arthroscopic portals. Anterior view.

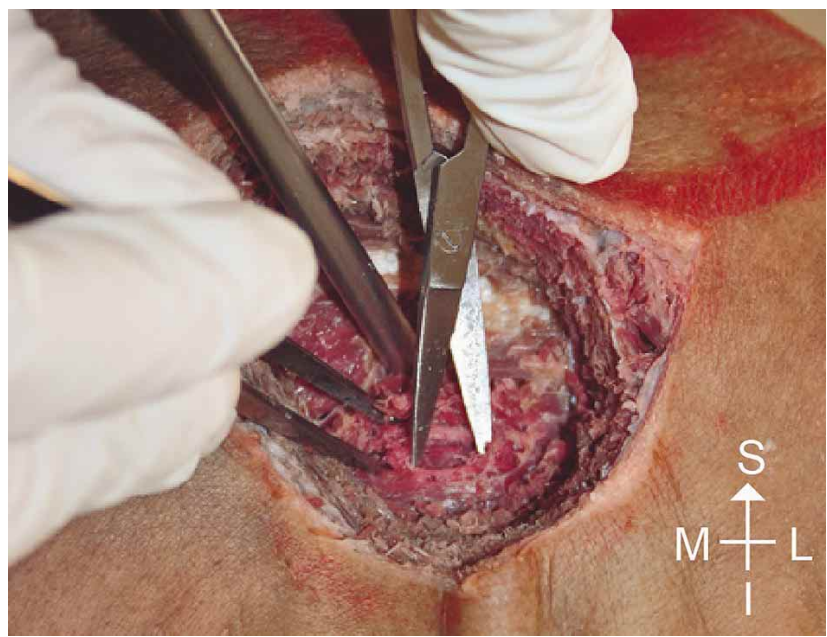

Fig. 2. Punch dissection technique used to evaluate the small microvasculature near the SPP (standard posterior portals).

Data Presentation . The structures at risk of being injured were graphically documented at each site by reporting their position within the circumference of dissection. Variables such as the diameter of each structure and the mean distance from the portal (all in millimeters) and the anatomical plane in which it was located were reported.

A circle and a clock hand system were used to graphically represent the neurovascular structures found in the dissection punch. In this system, 12 o'clock represents
Fig. 3. Vectorization of the photographs of dissections performed, translated to the vectorization format. The left shoulder dissection is shown such that it is possible to identify the trocar $(\mathrm{T})$, axillary artery (A), the deltoid branch of the thoracoacromial artery (R), and the coracoid process $(\mathrm{C})$. The SAP was placed using the insideout technique, and the photographs were taken at an angle between $15^{\circ}$ and $30^{\circ}$.

the upper end, 6 o'clock the lower end, and 3 and 9 o'clock represent the extreme right and left of the circle, respectively. The arterial, venous and nerve structures encountered during punch dissections were plotted.

Statistical Analysis . Microsoft Excel 2010 for Windows XP was used to calculate the mean and standard deviation for each measurement parameter. Parametric correlation tests (Student's $\mathrm{t}$ tests) were used to compare the mean values of the measurements made by the two observers regarding the distance to each trocar and the diameter of each structure. $\mathrm{P}<0.05$ was considered significant.

Ethical Considerations. This research protocol was approved by the local research ethics committee with the registration number AH11-003. There are no financial or commercial interests in the completion of this study, and therefore, the authors declare no conflicts of interest. 
ESPINOSA-URIBE, A. G.; MORALES-AVALOS, R.; GUTIÉRREZ-DE LA O, J.; GARCÍA-DE LEÓN, O. R.; TORRES-GARCÍA, J. K.; GUZMÁN-AVILÁN, K.; VÍLCHEZ-CAVAZOS, F.; DE LA GARZA-CASTRO, O.; GUZMÁN-LÓPEZ, S. \& ELIZONDO-OMAÑA, R. E. Safe areas for the placement of standard shoulder arthroscopy portals. An anatomical study. Int. J. Morphol., 33(4):1386-1392, 2015.

\section{RESULTS}

No significant differences in the mean results for each measured parameter were found between observers ( $\mathrm{P}$ values between 0.14 and 0.96). The morphometric characteristics obtained in each of the two portals are shown in Tables I and II.

Standard posterior portal. In $15.38 \%(n=2)$ of the dissections, we found two arterial structures: branches of the suprascapular artery and the circumflex scapular artery. A total of 88 venous structures of the superficial and deep venous plexus were observed in relation to the subcutaneous tissue and deltoid and infraspinatus muscles (Fig. 4). We also identified the lateral supraclavicular nerve from the cervical plexus in 3 cases. The morphometric and topographic parameters of the structures mentioned above are summarized in Table II.
Standard anterior portal. During $23.07 \%(\mathrm{n}=3)$ of the dissections, the axillary artery was detected in the lower half of the circumference dissected, together with the deltoid branch of the thoracoacromial artery. This artery presented a diameter of $2.99 \mathrm{~mm}$ and was found in direct contact with the trocar (Table I).

Presence of the cephalic vein, with a mean diameter of $5.06 \pm 0.73 \mathrm{~mm}$, was documented in $38.46 \%(\mathrm{n}=5)$ of the dissections. In total, 53 small-diameter venous structures at risk of being injured were found in all 13 dissections performed around this site (Fig. 5). The morphometric and topographic parameters of the structures mentioned are summarized in Table II. The characteristics of the structures at risk with a large diameter for the SAP are listed in Table I.

Table I. Neurovascular structures with a large diameter at risk during approaches through the SAP (standard anterior portals).

\begin{tabular}{lcccc}
\hline Structure at risk & $\begin{array}{c}\text { Frequency } \\
(\mathbf{n = 1 3 )}\end{array}$ & $\begin{array}{c}\text { Incidence } \\
\mathbf{( \% )}\end{array}$ & $\begin{array}{c}\text { Diameter } \\
\text { (Mean } \pm \text { SD) }\end{array}$ & $\begin{array}{c}\text { Distance to the trocar } \\
\text { (Mean } \pm \text { SD) }\end{array}$ \\
\hline Cephalic vein & 5 & 38.46 & $5.06 \pm 0.73 \mathrm{~mm}$ & $15.70 \pm 8.25 \mathrm{~mm}$ \\
Axillary artery & 3 & 23.07 & $7.73 \pm 2.59 \mathrm{~mm}$ & $16.65 \pm 7.12 \mathrm{~mm}$ \\
Brachial plexus & 1 & 7.70 & $8.0 \mathrm{~mm}$ & $8.31 \mathrm{~mm}$ \\
Without structures & 4 & 30.76 & --- & --- \\
\hline
\end{tabular}

Table II. Summary of results for each portal assessed.

\begin{tabular}{|c|c|c|c|c|}
\hline Portal & Variable & Arteries & Veins & Nerves \\
\hline \multirow[t]{5}{*}{ SPP } & Number of struc tures & 2 & 88 & 3 \\
\hline & $\begin{array}{c}\text { Diameter } \\
(\text { Mean } \pm \text { SD })\end{array}$ & $1.8 \pm 0.14$ & $1.23 \pm 1.32$ & $1.51 \pm 0.91$ \\
\hline & $\begin{array}{l}\text { Distance to the trocar } \\
(\text { Mean } \pm \text { SD })\end{array}$ & $15.58 \pm 2.27$ & $10.83 \pm 5.74$ & $13.88 \pm 0.54$ \\
\hline & Anatomic plane & Subcutaneous & Distributed in all planes & Subcutaneous \\
\hline & Safe areas & \multicolumn{3}{|c|}{$\begin{array}{c}\text { Between } 11 \text { and } 1 \text { o'clock for the left shoulder and between } 11 \text { and } 2 \\
\text { o'clock for the right shoulder. }\end{array}$} \\
\hline \multirow[t]{5}{*}{ SAP } & Number of structures & 18 & 53 & 4 \\
\hline & $\begin{array}{c}\text { Diameter } \\
(\text { Mean } \pm \mathrm{SD})\end{array}$ & $3.05 \pm 2.63$ & $1.81 \pm 1.29$ & $3.39 \pm 3.15$ \\
\hline & $\begin{array}{l}\text { Distance to the trocar } \\
(\text { Mean } \pm \text { SD })\end{array}$ & $10.76 \pm 8.42$ & $11.27 \pm 6.44$ & $11.84 \pm 4.45$ \\
\hline & Anatomic plane & Muscular & Distributed in all planes & Deep to the PMM \\
\hline & Safe areas & \multicolumn{3}{|c|}{$\begin{array}{c}\text { Between } 2 \text { and } 3 \text { o'clock for the left shoulder and between } 9 \text { and } 12 \\
\text { o'clock for the right shoulder. }\end{array}$} \\
\hline
\end{tabular}

$\mathrm{PMM}=$ Pectoralis minor muscle, $*=$ Both right and left shoulders. 


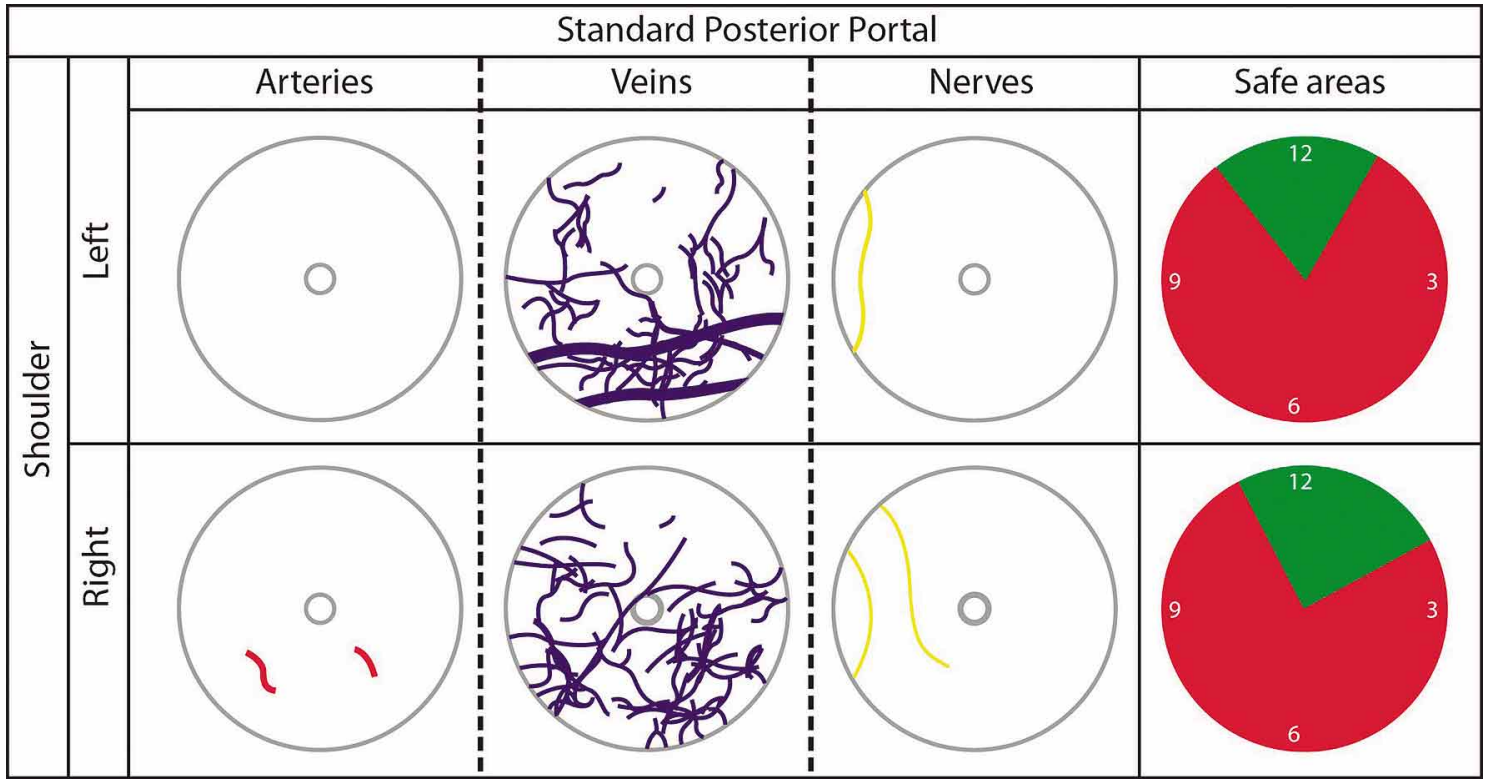

Fig. 4. Neurovascular structures at risk during posterior approaches and their relationship with the trocar (central circle). The safe areas (green) represent the lower density of digitalized structures inside the dissection circle.

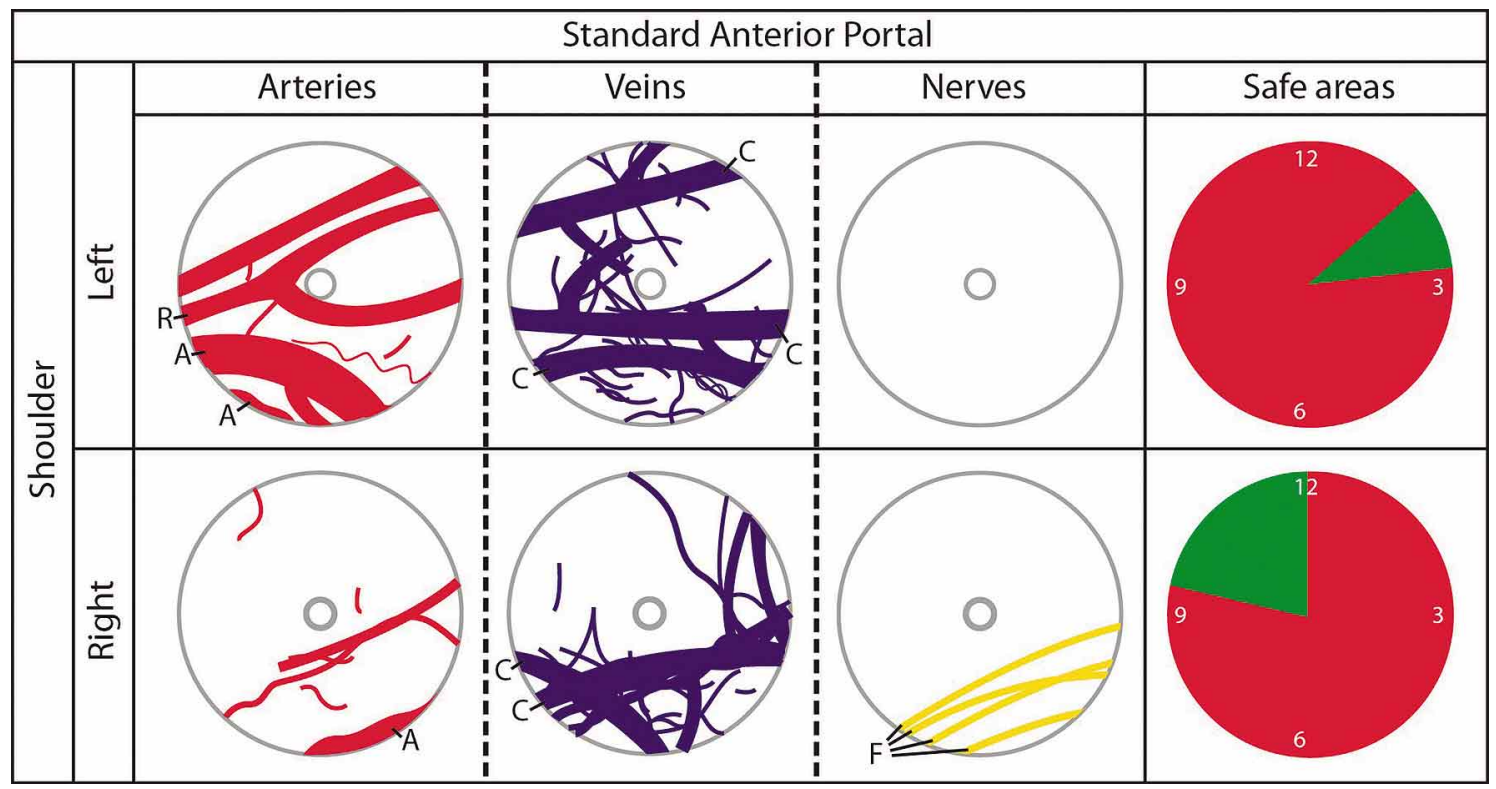

Fig. 5. Neurovascular structures at risk during anterior approaches and their relationship with the trocar (central circle). The safe areas (green) represent the lower density of digitalized structures inside the dissection circle. Areas at risk. (A: axillary artery; F: brachial plexus cords; R: deltoid branch of the thoracoacromial artery; C: cephalic vein).

\section{DISCUSSION}

Standard posterior portal. The SPP is important for visualization during arthroscopy (Andrews et al.; Wolf; Di Giacomo \& Costantini; Meyer et al.). Naidoo et al. found that the infraspinatus muscle is irrigated $81 \%$ of the time by the circumflex scapular artery and $94 \%$ of the time by the suprascapular artery, forming an anastomotic network between the two arteries. 
ESPINOSA-URIBE, A. G.; MORALES-AVALOS, R.; GUTIÉRREZ-DE LA O, J.; GARCÍA-DE LEÓN, O. R.; TORRES-GARCÍA, J. K.; GUZMÁN-AVILÁN, K.; VÍLCHEZ-CAVAZOS, F.; DE LA GARZA-CASTRO, O.; GUZMÁN-LÓPEZ, S. \& ELIZONDO-OMAÑA, R. E. Safe areas for the placement of standard shoulder arthroscopy portals. An anatomical study. Int. J. Morphol., 33(4):1386-1392, 2015.

Meyer et al. established that the suprascapular artery, is located at a mean distance of $27 \mathrm{~mm}$ from the center of the portal and a minimum distance of $24 \mathrm{~mm}$, is the anatomical structure at greatest risk of injury during posterior approaches of the shoulder. In our study, we show the presence of arterial structures on only two occasions. Therefore, although the infraspinatus muscle has an abundant arterial supply, the posterior portal is located in an area with relatively little arterial supply. As such, we propose a safe area located between 11 and 1 o'clock for the left shoulder and between 11 and 2 o'clock for the right shoulder. This proposal is mainly based on the wide distribution of small-diameter venous vessels.

In the present study, we located three cutaneous nerve branches. Therefore, we performed an open dissection of the same area, confirming the finding on all three occasions of the lateral supraclavicular nerve, which is derived from the superficial portion of the cervical plexus. These findings are relevant because of the possible injury to this nerve while using and manipulating this portal; without significantly affecting visualization, the chance of injuring the neurovascular structure is significantly decreased.

Quantification of the small-diameter structures found while performing a posterior approach has not been reported in the literature. Together, these structures could represent a source of intra-articular bleeding, which complicates visualization when performing a posterior approach. The presence of a safe area for SPP is located between 11 and 1 o'clock for left shoulder and 11 and 2 o'clock for the right shoulder.

Standard anterior portal . The SAP was placed in relation to the rotator interval, directing the trocar by transillumination from the SPP toward the coracoid process. This approach is important as a working portal for the treatment of diverse pathologies (Di Giacomo \& Costantini). Meyer et al. reported the presence of the cephalic vein in $50 \%$ of dissections; in two of these cases, direct injury occurred within a distance between 10 and $14 \mathrm{~mm}$. They also documented direct injury to the cephalic vein twice. Regarding arterial structures, Meyer et al. reported a mean distance of $33 \mathrm{~mm}$ from the axillary artery to the anterior portal. Cameron (1996) reported the presence of a pseudoaneurysm after shoulder arthroscopy due to an injury of the cephalic vein. Our results agree with those reported by Meyer et al. highlighting the presence of the cephalic vein in $38.46 \%(n=5)$ of the samples. In addition, we documented the presence of the axillary artery at risk in $23.07 \%(\mathrm{n}=3)$ of the sample at a mean distance of $16.65 \pm 7.12 \mathrm{~mm}$. Both structures were located between 3 and 9 o'clock in the dissection circle. These variations could be explained by the body positioning used in the different studies. In contrast to the beach chair position used by Meyer et al., we used the lateral decubitus position in our study. These results suggest a high risk of injury to vascular structures when performing an anterior approach at this point. Because these structures could represent an important source of transoperative bleeding, their locations should be considered to avoid complications.

In the SAP, the existence of important neurovascular structures such as the deltoid branch of the thoracoacromial artery, axillary artery, and brachial plexus cords was documented. In our study, this portal represents the approach site with the greatest possibility of damaging a neurovascular structure. A hypovascular area between 2 and 3 o'clock for the left shoulder and between 9 and 12 o'clock for the right shoulder was identified.

The sample size was the main limitation in conducting this study. The use of only male cadavers during this study represents another limitation. We suggest performing a similar study with a greater number of samples. However, this study has three significant contributions previously unstudied, first this study reports quantitatively the total number of small-diameter structures present in the two shoulder arthroscopic portals evaluated. Second, the study shows that in some cases it is possible to find high diameter neurovascular structures in close relation to the portals, which might be damaged at the time of placement and third, it proposes a new computational analysis method the creation of security and risk volumes which could be extrapolated to the analysis of other arthroscopic portals in any human joint. However, we recognize that the number of sample represents a strong limitation of the study, still, the sample in this study is similar to those used by other studies.

The results of this study provide the anatomical basis for the realization of subsequent basic and clinical studies, in which the safe areas proposed in this study must be evaluated to propose new access points for performing arthroscopic procedures on the shoulder.

\section{ACKNOWLEDGMENTS}

We wish to acknowledge the assistance of Jaime A. Cisneros Rios in preparing the graphic material presented in this study. 
ESPINOSA-URIBE, A. G.; MORALES-AVALOS, R.; GUTIÉRREZ-DE LA O, J.; GARCÍA-DE LEÓN, O. R.; TORRES-GARCÍA, J. K.; GUZMÁN-AVILÁN, K.; VÍLCHEZ-CAVAZOS, F.; DE LA GARZA-CASTRO, O.; GUZMÁN-LÓPEZ, S. \& ELIZONDO-OMAÑA, R. E. Safe areas for the placement of standard shoulder arthroscopy portals. An anatomical study. Int. J. Morphol., 33(4):1386-1392, 2015.

ESPINOSA-URIBE, A. G.; MORALES-AVALOS, R.; GUTIÉRREZ-DE LA O, J.; GARCÍA-DE LEÓN, O. R.; TORRESGARCÍA, J. K.; GUZMÁN-AVILÁN, K.; VÍLCHEZ-CAVAZOS, F.; DE LA GARZA-CASTRO, O.; GUZMÁN-LÓPEZ, S. \& ELIZONDO-OMAÑA, R. E. Áreas seguras para la colocación de portales artroscópicos estándar de hombro. Un estudio anatómico. Int. J. Morphol., 33(4):1386-1392, 2015.

RESUMEN: Las abundantes estructuras vasculares que rodean la articulación del hombro son complejas y variables, y dificultan los abordajes artroscópicos. El objetivo del estudio fue determinar áreas seguras y en riesgo en relación al portal posterior estándar y el portal anterior estándar y cuantificar la distribución de estructuras de diámetro pequeño e intermedio que puedan conducir a sangrado intraarticular durante la cirugía. El portal posterior estándar y el portal anterior estándar fueron colocados según su descripción en la literatura y fueron realizadas disecciones en sacabocado de $2,5 \mathrm{~cm}$ alrededor del trocar in situ. La disposición de cada estructura identificada fue documentada fotográficamente y digitalizada para cada plano anatómico. La distancia hacia el trocar y el diámetro de cada estructura fueron medidos. Basado en cada plano anatómico digitalizado, áreas de seguridad y riesgo tisular fueron determinadas y un sistema de coordenadas de manecillas de reloj fue utilizado para representar estas áreas. El área segura alrededor del portal posterior estándar fue localizada entre las 11 y las 1 en el sistema de las manecillas del reloj para hombros izquierdos y entre las 11 y las 2 para hombros derechos. Para el portal anterior estándar, el área segura fue localizada entre las 2 y 3 horas para hombros izquierdos y entre las 9 y 12 horas para hombros derechos. Aun así, se documentó el riesgo de lesionar la vena cefálica en 5 ocasiones, la arteria axilar en 3 ocasiones y la rama deltoidea de la arteria toracroacromial en una ocasión. Este estudio reporta cuantitativamente el número total de estructuras de pequeño diámetro presentes en los dos portales artroscopicos evaluados. Las áreas seguras propuestas en este estudio deben ser evaluadas para proponer nuevos puntos de acceso para la realización de procedimientos artroscopicos en el hombro.

PALABRAS CLAVE: Anatomía; Artroscopia; Portales; Áreas Seguras; Hombro.

\section{REFERENCES}

Andary, J. L. \& Petersen, S. A. The vascular anatomy of the glenohumeral capsule and ligaments: an anatomic study. J. Bone Joint Surg. Am., 84-A(12):2258-65, 2002.

Andrews, J. R.; Carson, W. G. Jr. \& Ortega, K. Arthroscopy of the shoulder: technique and normal anatomy. Am. J. Sports Med., 12(1):1-7, 1984.

Bigliani, L. U.; Dalsey, R. M.; McCann, P. D. \& April, E. W. An anatomical study of the suprascapular nerve. Arthoscopy, 6(4):301-5, 1990.

Burkhart, S. S.; Lo, J. K. Y.; Brady, P. C. \& Denard, P. J. The Cowboy's Companion: A Trail Guide for the Arthroscopic Shoulder Surgeon. 2nd ed. Philadephia, Wolters Kluwer/Lippincott Williams \& Wilkins, 2012.

Cameron, S. E. Venous pseudoaneurysm as a complication of shoulder arthroscopy. J. Shoulder Elbow Surg., 5(5):404-6, 1996.

Di Giacomo, G. \& Costantini, A. Arthroscopic shoulder surgery anatomy: Basic to advanced portal placement. Oper. Tech. Sports Med., 12(2):64-74, 2004

Ebraheim, N. A.; Ramineni, S. K.; Alla, S. R.; Biyani, S. \& Yeasting, R. A. Anatomical basis of the vascular risk related to the circumflex scapular artery during posterior approach to the scapula. Surg. Radiol. Anat., 32(1):51-4, 2010.

Gumina, S.; Alvino, P.; Giaracuni, M.; Vestri, A.; Ripani, M. \& Postacchini, F. The safe zone for avoiding suprascapular nerve injury during shoulder arthroscopy: an anatomical study on 500 dry scapulae. $J$. Shoulder Elbow Surg., 20(8):1317-22, 2011.

McGinty, J. B.; Burkhart, S. S.; Jackson, R. W.; Johnson, D. H. \& Richmond, J. C. Artroscopia Quirúrgica. Madrid, Marban, 2005.
Meyer, M.; Graveleau, N.; Hardy, P. \& Landreau, P. Anatomic risks of shoulder arthroscopy portals: anatomic cadaveric study of 12 portals. Arthroscopy, 23(5):529-36, 2007.

Naidoo, N.; Lazarus, L.; De Gama, B. Z.; Ajayi, N. O. \& Satyapal, K. S. Arterial supply to the rotator cuff muscles. Int. J. Morphol., 32(1):13640, 2014.

Pope, E. J.; Ward, J. P. \& Rokito, A. S. Anterior shoulder instability - a history of arthroscopic treatment. Bull. N. Y. U. Hosp. Jt. Dis., 69(1):44-9, 2011.

Shishido, H. \& Kikuchi, S. Injury of the suprascapular nerve in shoulder surgery: an anatomic study. J. Shoulder Elbow Surg., 10(4):372-6, 2001.

Stecco, C.; Gagliano, G.; Lancerotto, L.; Tiengo, C.; Macchi, V.; Porzionato, A.; De Caro, R. \& Aldegheri, R. Surgical anatomy of the axillary nerve and its implication in the transdeltoid approaches to the shoulder. J. Shoulder Elbow Surg., 19(8):1166-74, 2010.

Wolf, E. M. Anterior portals in shoulder arthroscopy. Arthroscopy, 5(3):2018, 1989.

Correspondence to:

Rodolfo Morales-Avalos M.D

Department of Human Anatomy

Faculty of Medicine

Universidad Autónoma de Nuevo León (UANL)

Ave. Madero s/n Col. Mitras Centro, Monterrey

Nuevo León, C.P.64460

MÉXICO

Email: rodolfot59@hotmail.com

Received: 11-04-2015

Accepted: 04-08-2015 